\title{
HIGHLIGHTING THE ANTITHESIS BETWEEN THE ICON - AS AN ILLUSTRATION OF HUMAN TRANSFIGURATION - AND POSTMODERN IDOLS
}

\author{
Dorina Gabriela MUREŞAN*
}

\begin{abstract}
The Edenic nostalgia has always remained in the soul of the fallen man. Because of this, the human being, which had retained the image of the grace of Divinity, has always aspired to rediscover this in himself. The reinstatement of the theandric community was accomplished by the incarnation of the Savior, which abolished the Old Testament ban regarding the representation of sacred realities. On this basis, the human being perceived the need to represent in icons both God and the saints. If God is the personification of the Absolute, the saints are illustrations of human nature transfigured by pneumatization. Therefore, the icon reveals itself to the believer as a permanent, eternal standard of morality, challenging him to gain the grace of God similarly to the saint or saints represented in the icon. Therefore, the icon is a viable alternative in the face of all the idols of the ephemeral world. Of the realities transformed into idols by an assiduous passion, which voids the soul of the divine grace and creates addiction, to name but a few: material possessions, the overemphasis of physical beauty, the worship of technological progress, the replacement of icons with images of celebrities/stars (posters), work overload etc. In antithesis, the icon reorients the human being to God, provoking him to activate the divine image inside him.
\end{abstract}

Keywords: prototype, idol, transfiguration, sacredness, Theophany, pseudomodels, pneumatization.

\section{Highlighting sacred images in great religions}

There has always been the desire to come closer to Divinity among humans. Different faiths of the world have tried to give man ways to

PhD candidate, Faculty of Orthodox Theology, "Babeş-Bolyai" University, ClujNapoca, Romania. 
achieve this goal; thus, making a retrospective of the religions with the largest number of followers we find that in all there is a revealing person that facilitates the way of its followers to God, or one or more representations of the founder of the faith and its followers, who achieved perfection by following his recommendations.

It is in Judaism when occurs the conception according to which God “... manifests through His attributes of justice and love as a judge, He comes to judge the world ... and His mercy must always be implored"1 . In this way He states: "Pray for My mercy to supersede My righteousness, that I may be only kindness to My children on the earth!"2. In the above-mentioned religion, the Messiah's image appears as a hope for the renewal of the divine - human covenant, the Messiah being a personification of the sacred that any Jew would want to meet.

According to the researchers of the History of Religions in Islam it is because Allah is designed as superior to the telluric universe that he is not conceived in any way, instead in the mosques appear different pictures of the prophet Muhammad, the founder of this religion considered to be the last great prophet of Islam by its followers. He attributes a sacred valence to the symbol of crescent that marks the domes of mosques tacitly expressing the worshippers' belonging to Islam.

In Buddhism both Buddha statues found in yoga lotus position and worshipped in temples are considered sacred, and various traces of his steps occur, especially in Sri Lanka, as well.

As specified in the official Hinduism, we do not encounter any divine image, as this faith affirms the existence of an impersonal deity called Brahman, with whom the Hindu merges after death the spiritual element of his being (soul appropriately) called Atman. However, it is in Hinduism that first appears yoga as a mystical-religious system, which is modeled on the image of Ishvara to whom the yogis aspire and who is considered by the scholars of the Religious History: "the God of the yogis"3.

All the images mentioned above are only attempts to illustrate a

${ }^{1}$ Philippe Gaudin, Marile religii: Judaism, Creştinism, Islamism, Hinduism şi Budism, Bucureşti, Horizons Publishing House, \& Leader Publishing House, 2015, p.72.

${ }^{2}$ Apud Philippe Gaudin, The Great Religions..., p. 73.

3 Mircea Eliade, Yoga. Nemurire şi libertate, Bucureşti, Humanitas Publishing House, 1993, p. 122. 
reality considered sacred, that human beings cannot afford to give the ability of a facilitator element of its connection with the Divine. This inability is generated both by the dogmas of various religions, and by the fact that man is dominated by the feeling of grandeur awareness of the reality which he loves.

Christianity stands out from other faiths through its different way of relating to God. Thus, in Christianity only is the idea of a unique Divinity present through its single divine nature and divine Trinity due to the number of His People. We note the superiority of the personal nature of the Supreme Being as, if This were impersonal, man could not establish a dual relationship of communication and communion with Him; while in this situation Divinity would not prove to be an entity loving people and blessing their lives.

The dogma of the existence of a Trinitarian God is characteristic to Christianity and focuses on love as a way of relating between Divine hypostases. Revealing this it is found that "the character of loving person necessarily attracts the three-personal existence, i.e. fully loving ... love in one person is still selfish; only love between two people ... is still closed and therefore subjective. Only the third person ...love opens and objectifies. It's a geometric balance which cannot be achieved, it is not stable except for three supporting points." 4

Just as in People-Thirds the existence of the divine nature is maintained, without each being denied the attributes and the human intellect, will and feeling are different capacities of the same soul, whose unitary character is not affected by their presence. Except for the religion mentioned above, all religious systems reject the idea that the bringer of revelation in the world could be God himself and that he can approach man so much as to embody kenotic renouncing but to His divine nature.

"Christ the image of God is not considered kidnapping to be just with God, but He emptied himself taking the form of a servant being made in human likeness, obedient to death, even death on a cross." (Phil., 2:7-9).

The foundation of rejecting the idea of the Incarnation by other religions is the recital according to which through His quality itself, the

${ }^{4}$ George Remete, Dogmatica Ortodoxă, Alba Iulia, Reîntregirea Publishing House, 2007, p.151. 
Creator is superior to the human being, that is why He cannot be totally communicated, and if they tried to do this, man as the recipient of revelation would not withstand a direct spiritual meeting with Him.

Given the three-personal character of the Trinity God, we fight the idea stated above stressing that revelation can derive from being a common person who is common both to God and to human beings.

If this attitude was based in other religions on fear of falling into idolatry because it was considered impossible to represent God, the Incarnation of the Savior is an act by which God enters into relationship with man becoming visible to him. The possibility for the Creator to enter history through Incarnation is the basis of iconic representations and it is another novelty brought by Christianity in the religious landscape of the world.

Based on the biblical statement that "God is love" (I John 4:8), it is obvious that He can and wants to reveal himself to the human persons, and they are able to feel the love of God and to receive the revelation that $\mathrm{He}$ makes about Himself. We note that in other religions the sacred images are not revealed by divinity; the Christian icon is based not only on the humility but also on the love of God to man, as He became incarnate not only to become accessible to him, but also to prove both that He cannot remain indifferent to him, due to the love for him, and that he wants to transmit personal revelation.

Due to the fact that it is God or His friends, the saints, represented in it, the icon sanctifies the world and has a soteriological role for this because it is a concrete way in which contact between the Creator and people is facilitated.

\section{The icon as an artistic-cult object}

According to biblical accounts, the author of the first icon is God who created man "in His own image" (Gen. 1:26-27) establishing the purpose of obtaining spiritual likeness to Him embodied in a state of holiness. Given this fact we find that man becomes a living icon of his Creator. Human beings are designed differently than other creatures even by the hand of divinity and received the breath of life from God becoming thus capable: "...that besides a biological life have a spiritual and rational 
life"5.

After the fall of man from a paradisiac state, his nostalgic state after a genuine relationship between him and God preserved and enhanced over time. The icon wakes or according to the case reactivates in the faithful people the desire to search the sacred both in the world and in themselves. Reflecting both this and that aspiration to the Creator can become ardent, Psalmist David says: "In what way would the deer springs of water, so my soul pants for you, O God, my soul thirsts for the living God." (Psalm 41:1-2)

In terms of cultic the veneration of the icon is meant to evoke the man his purpose, to materialize the divine image that it carries within itself; therefore, its worship does not address the material from which it is made, but converges to the prototype it represents. The challenge of the icon for the worshipper is to activate the divine image he was created after thus becominhimself an icon.

According to the Holy Tradition the first non-hand-made icon known in history is the appearance of the Savior sent by him to King Avgar to facilitate his healing.

The fact that there are more icons of the same event or the same sacred person proves that, if obeyed the canons of the Church, the iconographer is given freedom to bring in his share to some extent in creating the icon.

Orthodoxy says that between grace and freedom there is a working relationship. This point is highlighted by the existence of a prayer that the iconographer must read before starting painting. The invocation specified requires divine help to create the icon, which is why the Holy Spirit performs a miracle pouring grace over the painter and helping him to materialize the icon which, before its existence as an object, reflects concreteness in the desire of the painter to glorify God. We can therefore say that each image carries within itself the theandric collaboration as its own secret.

From the above we conclude that the iconographer is an exponent of the universal priesthood, following the humility example of the saint he is

5 Sofian Brașoveanul, Omul - icoană a lui Dumnezeu, icoana - chip al omului indumnezeit, retrieved from https // www. cbrom. of / index.servants / articles/ 28, (accessed on 02.23.2017). 
painting, because like him, he does not project himself but God. Emphasizing parallelism between the mission of the priest and the mission of the iconographer it is stated:

"The mission of the icon painter and that of the priest have much in common. According to Saint Theodosius Monk, for example 'one composes the Body and the Blood of God (in the Mass) and the other represents Him (in the icon)'. Like the priest, the painter's task is to put us all through his art, in front of the same reality, leaving each person free to respond up to his skills, according to its nature and circumstances of life." 6

We mention three pictorial elements specific to the icons: no profile of the image shown, the way the painted person is oriented and the layout of the running point: “... Saints are always represented front or threequarters turned towards the viewer. Almost never are they seen in profile, not even in complicated compositions, indeed the profile interrupts somehow the communion; it is like a beginning of absence. There is acceptance only for representing characters who have reached holiness, such as shepherds or magi of the Nativity icon. This lack of profile is one of the expressions of the intimate relationship of the one who prays and the saint represented." 7

Compared with paintings, some icons (especially glass) are painted the other way around, which further illustrates their sacredness. This aspect, also called reversed perspective in painting, highlights their purpose of orienting the viewer's reason or the prayer's reason towards the transcendent world, because their role is to convince the latter to question about the moral renewal of their own lives in order to get himself the state of holiness.

Named the Bible of the illiterate by the theologians, the icon in its entirety continuously updates biblical events or restores in the collective memory the images of saints as models. An item that appears in both paintings and icons is the escape. He is positioned differently in icons than in paintings. Here is its definition and the emphasis of its role:

“... The vanishing point is the point of intersection of the lines in the

${ }^{6}$ Leonid USPENSKY / Boris BoBrinsKoy / Stephan BIGAM / Ioan BIZĂU, in Ce este icoana?, Alba Iulia, Reintregirea Publishing House, 2005, p.23.

${ }^{7}$ Leonid USPENSKY et al, Ce este icoana?, p.27. 
background of a painting ... it is used to give the impression of distance or depth ... in paintings the painting lines that create the impression of convergence gathers into one point behind the image.

In this convergence, the icon moves to the front of the image ... that is because the running point is behind the viewer making him an integral part of the action presented by the icon. In other words, the viewer is called to be not only the viewer but also a participant in the Gospel ... For ... the icon is nothing but the Gospel in images that opens the worshiper the perspective of eternity because the running point is never reached." 8

Unlike other images that are simple attempts to represent different sacred realities, the icon is becoming unique through its illustration of the human nature transfigured by spiritualization. The saint or saints represented are not only symbols of the transcendent world, but people who have integrated into it, after living a life where divine-human harmonization and the principles of Christian ethics have reached the highest levels.

For the reason specified the icon develops the religious feeling of the one who requests the prayers of the saints represented in it.

\section{Brief characterization of modernism and postmodernism}

According to historians the modern age "is between the late Middle Ages and the French Revolution." 9

The same experts inform us that modernism was originally an artistic movement that materialized revolt against classicism. Over time what was in the initial phase only a style that had influenced many arts was converted into an ideology which caused a rejection of the values that were previously considered not only valid but also immutable. So if until modern times the religion was considered the supreme principle by which people oriented their lives trying to factually materialize its principles, the modernism substituted the image of God the spiritual Father of mankind to that of a punitive judge, punishing sinners with a sadistic pleasure.

The modern man has come to isolate God in His own sidereal world

${ }^{8}$ Lazăr PUHALO, Icoana ca Scriptură, Oradea, Theosis Publishing House, 2009, pp 38-39.

${ }^{9}$ Claude KARNOOUH, De la modern la modernitatea (post) în Europa şi câteva reflecţii în jurul căderii comunismului!, retrieved from www.arguments_and_facts.ro, (accessed in 06.04.2017). 
because, not growing a filial relationship with Him anymore, he felt constrained by moral precepts of his own faith. In this context "in the late nineteenth century, various philosophers like Nietzsche and Heidegger come to speak about two striking facts: the first concludes that God is dead and the other states that this is why He needs a substitute" 10 .

If modernism refused God, it was seeking to identify its own certainties in the earthly reality. By contrast, postmodernism, also started as an artistic trend and turned into an ideology, relativizes reality itself attempting to replace God through a series of idols that will be discussed further by relating them to the icon, seen as the only image of glory.

The ideology analyzed promotes secularization concluding that religiosity must act solely in the interior plan. Human quality is no longer appreciated and this reduces man to the quality of a simple link in a chain of existences. Inner strength is no longer based on the evangelical urge "Seek first the kingdom of God and His righteousness and all will be added unto you" (Matthew 6:33) and the man feels overwhelmed by the need to solve problems minimizing the divine help.

Paradoxically, the XXI-st century postmodern man tends to become a slave of the technology originally designed to make life easier for him, he does not take the information from books any longer but relies on the Internet only and believes that without divine aid he can solve the problems he faces. Except for the mentioned ideas, he has an almost total distrust in everything his predecessors have achieved, and relativizes the history itself; the postmodern man is bombarded daily: "with images and ideas which may have the adverse effect of emptying of meaning ..."11.

\section{Presentation of the icon and postmodern idols antithesis}

In the context stated we notice the existence of a neopoliteism phenomenon; of all realities that may be considered idols of the postmodern period we mention: the stress of caring for keeping material possessions, the exaggerated cultivation of physical beauty, the worship of technological

${ }^{10}$ Gianni VATtimo, A crede că mai credem: e cu putinţă să mai fim creştini înafara Bisericii, Constanţa, Pontica Publishing House, 2005, p.28.

${ }^{11}$ Mircea MicLE, Religie şi Spiritualitate in postmodernism [Religion and spirituality in postmodernism], retrieved from www.speech.ro/2016/religion-and-spirituality-inpostmodernism (accessed on 02.23.2017). 
progress, the stars whose images became posters tend to be given as models.

\subsection{The stress of caring for keeping material possessions}

This is a reality that has permanently dominated history and that tends to define the postmodern period. If in other ages man refers to God and was developing his religiosity relating to the Creator by a quasi-fellow relationship considering that his own life is an indication of His existence, after the alleged "death of the Divinity ... man no longer defines by reference to a transcendent Being (so by the verb to be) but by the word to possess; the non-gracious person believes that This must be substituted with as many material possessions.

Even the conventional compliance of the Decalogue in some cases can not satisfy the desire of accumulation of goods, as demonstrated by the attitude of the rich young man mentioned by the Gospel (Luke 18:18-23). We also found that grasping causes the grower to become anonymous in front of the Divine. This is evidenced by another parable mentioned by the same evangelist (Luke 16:19-29).

Although Christianity does not condemn wealth itself, it stresses that this, as life itself and all that maintains it, is a divine gift and should not be turned into an end in itself. Instead of celebrity which is usually associated with material wealth, the icon proposes an alternative image of a person who overcame his own passions accumulating in exchange the spiritual treasure of virtues. In their quality of "friends of God" (John 15:14) and members of the triumphant Church, saints are authentic models of people who standing out of the desire of material accumulations obtained instead the spiritual treasure of virtues.

Generally, in the Church the idea that many saints are anonymous (as evidenced by the existence of the calendar Sunday of All Saints, which succeeds the feast of the foundation of the Church) opposes the public image and the fame accompanying a public star. Likewise, the publicity of a public star, the Church gives as alternatives two attitudes allowed before icons: the prayer as an expression of the conversation between worshipers and saints on the icons and the cult as a concrete expression of veneration made indirectly to God by worshiping his friends.

\subsection{Overemphasis of physical beauty}

The icon shows the prayer an image transfigured by grace, which 
has its source in the soul of the person represented in it, because it caught the divine beauty to the extent that it is accessible to man and can pass it to his own body. In this regard, it is stated: "The man whose soul has become wholly fire, gives some of the glory reached about inner ways forward to his body just as the material fire acts forward on fire." 12 For this reason, the prototype of the icon does not preach itself but sends human mind to divine transcendence, which is the source of its beauty.

An important characteristic of icons is that they keep for eternity the connection with their prototypes. In this regard, it is stated: Without denying the importance of maintaining harmony and natural beauty, we emphasize that in most post-modern societies it came to be regarded as a standard of morality and somatic functionality of the person.

There is no dispute that if he converts, as recommended by St. Apostle Pavel in a pneumatology temple, the body can become sacred (I Corinthians 6:19) but we emphasize that if the person as a whole, is not working on the spiritual image of God in which he was created, the body remains only a form without substance designed to spark with its attractiveness the eroticism of the others. In this context, a person with no grace can become a fake god, who sends thoughts to nothing transcendent and thus denies his value even if his images would appear on the cover of the most popular magazines.

\subsection{Worship of technological advances}

Technology has a prominent role in the permanent development of the society. Among the devices created with its help we can mention the $\mathrm{TV}$, the radio, the computer, the cell phone etc. It fulfilled a dual role facilitating the transmission of information and the industrial development achieved by specific technical systems simultaneously reducing man to the image of a simple information consumer or the person who just handles devices which facilitate the work. By using them in an exaggerated way, the individual risks becoming indiscriminate, no longer exploits time and the eternal relationship with God portrayed in icons is flawed.

\subsection{Replacement of icons with images of celebrities/stars(posters)}

The aspiration to success is quasi-general human, one of its

${ }^{12}$ Sf. SymeOn the New TheOlogian, Catechesis 83, apud Leonid UsPensky et al., Ce este icoana? p.28. 
embodiments is the desire of celebrity; although it is not negative in itself it can become negative though if - in order to achieve it - non-ethical means are used or when it comes from the tendency of a person to be different from his peers. An example of this attitude is the hit of a musical group whose message is the idea (We are the others). Analyzing this statement a remarkable contemporary theologian asks: "The others to whom? To everyone and to no one! Here it should be noted that this is not a simple dispute between subjectivity and objectivity, but the refusal of reality" ${ }^{\text {"13 }}$.

Those who advocate compliance with the principles of fashion (music fashion included) will tend to replace the icons in their usual space with various posters not only of music stars but of all stars admired.

Without combatting the idea that everyone has the freedom to choose a model to admire we mention that, no matter who owns the poster, it cannot provide but a fleeting image. Those who have perhaps the tendency to say that icons are obsolete as they permanently present images of well-known sacred persons, are being kindly addressed two rhetorical questions: Since the icon is a theophany that really represents human nature transfigured and perpetuated, can eternity ever become obsolete? Because we do not know the degree of spiritual evolution of the person / people represented in a poster, can I be certain that they will permanently serve them as a model, a purpose that the icon can achieve, though?

If the replacement of icons with posters is done just to keep up with the world, our warning is that basically "in existence it is not the action of the world upon the soul but the action of the soul upon the world"14.

The present study has the premise that the religious feeling is not just one characteristic of a human being, but a defining one for the person himself. For this reason I have made a brief incursion into the history of religions, to highlight the universality of aspiration towards Sacredness. In opposition with postmodern idols, that are ephemeral realities, the icons are proposed to the worshiper as perpetual calls to the rediscovery of an authentic relationship with a living and eternal God and His friends the saints. Their secret lies in the fact that they launch to the prayer the calling to eternity, relying on God's revelation.

${ }^{13}$ George REMETE, Fiinţă şi Credinţă, Vol. 3, Bucureşti, Paideia Publishing House, 2016, p. 570.

${ }^{14}$ IDEM, Cunoaşterea prin tăcere, Alba Iulia, Reîntregirea Ppublishing House, 2004, p. 443. 


\section{References:}

1. Biblia sau Sfânta Scriptură, Bucureşti, Editura Institutului Biblic şi de Misiune al Bisericii Ortodoxe Române, 2000.

2. Eliade, Mircea, Yoga. Nemurire şi libertate [Yoga. Immortality and freedom], Bucureşti, Humanitas Publishing House, 1993.

3. GAUDIN, Philippe, Marile religii: Judaism, Creştinism, Islamism, Hinduism şi Budism [The Great Religions: Judaism, Christianism, Islamism, Hinduism and Buddhism], Bucureşti, Horizons Publishing House, \& Leader Publishing House, 2015.

4. KARnOOUH, Claude, De la modern la modernitatea (post) în Europa şi câteva reflecţii în jurul căderii comunismului! [From modern to modernity (post) in Europe and several reflections about the fall of communism], retrieved from www.arguments_and_facts.ro, (accessed in 06.04.2017).

5. MICLE, Mircea, Religie şi Spiritualitate in postmodernism [Religion and spirituality in postmodernism], retrieved from www.speech.ro/2016/ religion-and-spirituality-in-postmodernism (accessed on 02.23.2017).

6. Puhalo, Lazar, Icoana ca Scriptură [The Icon as scripture], Oradea, Theosis Publishing House, 2009.

7. REMETE, George, Cunoaşterea prin tăcere [Knowledge through silence], Alba Iulia, Reîntregirea Publishing House, Alba Iulia, 2004.

8. Remete, George, Dogmatica Ortodoxă [Orthodox Dogmatic], Alba Iulia, Reîntregirea Publishing House, 2007.

9. REMETE, George, Fiinţă şi Credinţă [Being and Faith], Vol. 3, Bucureşti, Paideia Publishing House, 2016.

10. Sofian Brașoveanul, Omul - icoană a lui Dumnezeu, icoana - chip al omului indumnezeit [Man-icon of God, icon - face of deifeied man], retrieved from https//www.cbrom.of/index.servants/articles/28, (accessed on 02.23.2017).

11. USPENSKY, Leonid / Boris BOBRINSKOY / Stephan BIGAM / Ioan BIZAU, What is the icon?, Reunification Printing House Alba Iulia, 2005, p. 27.

12. VAtтimo, Gianni, A crede că mai credem: e cu putinţă să mai fim creştini înafara Bisericii [To believe that we still believe], Constanţa, Pontica Publishing House, 2005. 